\title{
The skeleton elephant trunk: A technique looking for an indication
}

\author{
Ourania Preventza, MD, ${ }^{\mathrm{a}, \mathrm{b}}$ Vicente Orozco-Sevilla, MD, ${ }^{\mathrm{a}, \mathrm{c}}$ and Joseph S. Coselli, MD ${ }^{\mathrm{a}, \mathrm{b}}$
}

\footnotetext{
From the ${ }^{\mathrm{a}}$ Division of Cardiothoracic Surgery and ${ }^{\mathrm{c}}$ Surgical Research Core, Michael E. DeBakey Department of Surgery, Baylor College of Medicine, Houston, Tex; and ${ }^{\mathrm{b}}$ Department of Cardiovascular Surgery, Texas Heart Institute, Houston, Tex.

This work was not funded by a grant or any other source of external funding.

Disclosures: J.S.C. participates in clinical research trials conducted by Edwards Lifesciences and Bolton Medical; consults for, receives royalties and a departmental educational grant from, and participates in clinical trials for Vascutek Terumo; and consults and participates in clinical trials for Medtronic, Inc, and W. L. Gore \& Associates. O.P. consults for Medtronic, Inc, and W. L. Gore \& Associates, and has received travel expenses from Cook Medical, Inc. The remaining author has nothing to disclose with regard to commercial support.

Received for publication July 13, 2018; accepted for publication July 16, 2018; available ahead of print Aug 21, 2018.

Address for reprints: Ourania Preventza, MD, Division of Cardiothoracic Surgery, Michael E. DeBakey Department of Surgery, Baylor College of Medicine, BCM 390, One Baylor Plaza, Houston, TX 77030 (E-mail: preventz@bcm.edu).

J Thorac Cardiovasc Surg 2018;156:e201-2

$0022-5223 / \$ 36.00$

Copyright (C) 2018 by The American Association for Thoracic Surgery

https://doi.org/10.1016/j.jtcvs.2018.07.037
}

The treatment of DeBakey type I acute aortic dissection has evolved with endovascular technology. The principle, however, remains the same: getting the patient out of the operating room alive and dealing later with concerns about long-term issues and disease progression.

In this issue of the Journal, Rupprecht and colleagues ${ }^{1}$ describe deploying a bare metal stent antegrade into a dissected arch with no intimal tear as a way to stabilize the aortic wall. Rupprecht and colleagues ${ }^{1}$ are to be commended for pushing the envelope. Previously, uncovered stents have been used to treat complicated type B aortic dissection in an effort to improve true-lumen perfusion and diameter; however, this technique failed to suppress false-lumen patency completely and to prevent stent fractures and migration necessitating reintervention. ${ }^{2,3}$ No solid data thus currently exist regarding the benefit of uncovered stents for treating complicated type B aortic dissection. Hybrid techniques for treating acute DeBakey type I aortic dissection have been introduced in an effort to increase aortic event-free survival and to decrease reinterventions without increasing short-term mortality or morbidity. ${ }^{4}$

According to Rupprecht and colleagues, ${ }^{1}$ in repairing an acute type A aortic dissection, the downside of not using a covered stent in the descending aorta beyond the left subclavian is the risk of leaving behind an "untreated arch." Some would argue that the native arch that is left behind during hemiarch and antegrade stent delivery is only a V-shaped piece of native aortic tissue, which includes the base of the innominate artery, the left common carotid artery, and, potentially, the left subclavian artery, and that no one knows whether this small piece of native aorta resolve the issue.

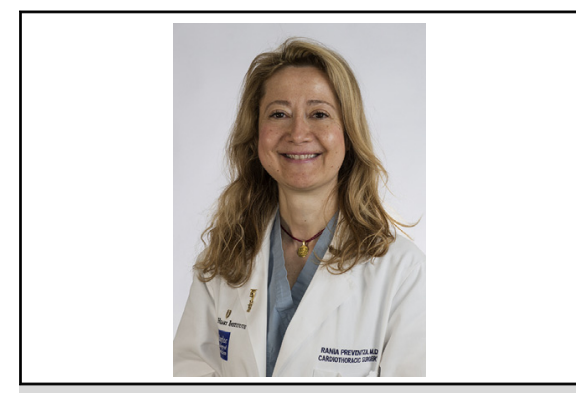

Ourania Preventza, MD

Central Message

In treating type A aortic dissection, keeping things simple is imperative. Keeping the patient safe with great outcomes and simultaneously pushing the envelope is our responsibility at all times.

See Article page e199.

would create any issues in the ensuing years. Furthermore, if the patient has cerebral malperfusion, stenting the carotid artery under direct vision during circulatory arrest could potentially resolve the issue without the need to place an uncovered stent across the arch. In addition, if the arch is really dilated, total arch replacement is the treatment of choice, and an uncovered stent will not

All of these arguments leave us with the question of which patients, during treatment of an acute type A aortic dissection, would benefit from an uncovered stent across the aortic arch without incurring an increased risk of stroke. Any time that surgeons do not treat the immediate problem and instead address long-term issues that may or may not arise, the presumption is that increasing the complexity of the procedure will not also increase mortality risk. Our strategy is to keep things simple in an already complicated disease process. Although Rupprecht and colleagues ${ }^{1}$ are to be congratulated for developing their technique, when this technique should be used is unclear. Introduction of a new way of doing things is always welcome if we have specific indications and reasons to expand the use of current technology for our patients' benefit. Certainly, hybrid procedures for acute type A aortic dissection are highly effective in 
selected patients with specific indications. ${ }^{3}$ The described technique will trigger discussion regarding indications, the sizing of the uncovered stent, the risk of further aortic arch dissection by the radial force of the uncovered stent, the difficulty of subsequently placing a covered stent, and the challenges involved in removing the uncovered stent if the arch becomes dilated with time. All these questions are difficult to answer with a single case report; however, this report does open the door to creating a new platform involving different configurations of the elephant trunk.

\section{References}

1. Rupprecht L, Kasprzak P, Schmid C, Kobuch R, Pfister K. The use of an uncovered stent in type A aortic dissection during open aortic surgery. J Thorac Cardiovasc Surg. 2018;156:e199-200.

2. Lombardi JV, Cambria RP, Nienaber CA, Chiesa R, Teebken O, Lee A, et al; STABLE investigators. Prospective multicenter clinical trial (STABLE) on the endovascular treatment of complicated type B aortic dissection using a composite device design. J Vasc Surg. 2012;55:629-40.e2.

3. Preventza O, Cervera R, Cooley DA, Bakaeen FG, Mohamed AS, Cheong BY, et al. Acute type I aortic dissection: traditional versus hybrid repair with antegrade stent delivery to the descending thoracic aorta. J Thorac Cardiovasc Surg. 2014;148:119-25.

4. Canaud L, Faure EM, Ozdemir BA, Alric P, Thompson M. Systematic review of outcomes of combined proximal stent-grafting with distal bare stenting for management of aortic dissection. Ann Cardiothorac Surg. 2014;3:223-33. 